\title{
Testing For Purchasing Power Parity In A Panel Of Middle-Eastern Countries
}

Hala El-Ramly, (E-mail: helramly@aucegypt.edu), American University - Cairo, Egypt

\begin{abstract}
The attention given to testing for purchasing power parity (PPP) using middle-eastern data has so far been very limited. This paper tests for PPP in a panel of twelve countries from the Middle East. Four different unit root procedures are used to test for the mean reversion property in the real exchange rates of these countries. The evidence in support of PPP in the tested panel is generally found to be weak.
\end{abstract}

\section{INTRODUCTION}

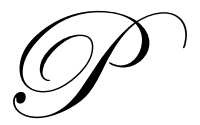

urchasing power parity (PPP) is the simple idea that exchange rates between currencies are in equilibrium when their purchasing power is the same in each of the two countries. This means that a unit of currency can buy as much goods and services in one country as its equivalent in foreign currency can buy in the foreign country. Whether PPP holds or not has very important implications for any group of countries. For example, most developing countries have lots of potential for growth through investment projects. However, long term investment decisions require currency forecasts that extend far into the future. Being the foundation of much of exchange rate economics, the concept of PPP is often used to determine the long term equilibrium exchange rate for currencies. As mentioned by Taylor and Taylor (2004), the concept that exchange rates adjust to the level determined by PPP is important for countries regardless of what their exchange rate arrangement is; This is because countries with fixed exchange rates "need to know what the equilibrium exchange rate is likely to be and countries with variable exchange rates would like to know what variation in real and nominal exchange rates they should expect". Other than the fact that PPP is important as a theory of exchange rate determination, there are many other reasons why it is important for it to hold. Edwards (1989) finds that persistent misalignment of the exchange rate is associated with lower economic growth rates. Also, Engel and Rogers (2001) show that there is a welfare loss associated with deviations from PPP that comes from consumers in different countries paying different prices. Moreover, the concept of PPP is indispensable in making international comparisons of income.

There are two versions of PPP: an absolute version and a relative version. The absolute version (which builds on the law of one price) holds if the nominal exchange rate between two countries' currencies equals the ratio of their aggregate price levels. This implies that the real exchange rate should be equal to one. On the other hand, the relative version of PPP only requires that the change in the nominal exchange rate be equal to the difference in the inflation rates of the two countries. For this weaker form of PPP to hold, the real exchange rate does not have to equal one but it has to be constant. An alternative way of looking at it is that the real exchange rate should be mean reverting, always returning to its equilibrium level whenever it deviates away from it. Thus, searching for evidence of long-term PPP has very often taken the form of tests for the mean reversion property of the real exchange rates.

Being an extremely important relation in any open economy macroeconomic model, a large amount of research $^{1}$ was done to test for PPP in industrialized countries. However, the existing research on PPP in the Middle East in general and in the Arab countries in particular has been very limited and has produced mixed results. Using quarterly data over 1971-1994, Bahmani- Oskooee (1998) tests for PPP by testing the stationarity of the real effective exchange rates of 11 Middle Eastern countries ( 9 Arab countries, Iran and Turkey) using both KPSS (Kwiatkowski et al., 1992) and ADF (Augmented Dickey Fuller) univariate unit root tests. While in most cases the results of the KPSS test supported PPP, the ADF test did not. Soofi (1998) uses cointegration and fractional cointegration methods to test for the mean reverting property in monthly parallel market US dollar rates for several OPEC countries and finds that 
the PPP models for some of the countries including Algeria and Saudi Arabia are fractionally integrated. Using ADF tests, he is unable to find evidence for the mean reversion property in the data. Salehizadeh and Taylor (1999), using monthly observations for the post-Bretton Woods period of 1975-1997, test for PPP for a group of 27 developing countries that include 4 Arab countries namely Algeria, Bahrain, Egypt and Morocco. Applying cointegration tests of price indices and exchange rates, they find evidence in favor of long term PPP as a cointegration concept in 14 countries including Bahrain, Egypt and Morocco. Further tests on the real exchange rates failed to find evidence for the symmetry (between domestic and foreign prices) and the proportionality (between relative prices and the exchange rate) properties implied by PPP. Moreover, ADF unit root tests could not give support to PPP in the data of these countries. Sarno (2000) applies multivariate nonlinear models to quarterly data for 12 Middle Eastern countries (9 Arab countries, Iran and Turkey) for the post-Bretton Woods period and finds evidence for highly nonlinear reversion of real exchange rates to a stable equilibrium in the countries examined. As for panel methods, Hassanain (2004) applies IPS (Im et al., 2003) panel unit root test on annual data for a panel of 10 Arab countries ${ }^{2}$ from 1980 to 1999 and is able to reject the unit root null with a number of different base currencies.

The purpose of this paper is to extend the literature on using panel unit root tests to search for evidence for PPP in the real exchange data of countries from the Arab world. When PPP holds, the real exchange rate displays long-run mean reversion. Thus testing for the validity of PPP relies on testing for unit roots in real exchange rates. If the real exchange rates are found to be stationary and the unit root hypothesis is rejected, PPP is believed to hold. Thus the paper proceeds to test for unit roots in the real exchange rates of the twelve countries used in this study. Four different unit root tests are conducted for this purpose namely the univariate Augmented Dickey Fuller (ADF) test; the Im, Pesaran and Shin (IPS) test; the Levin and Lin (LL) test and the Seemingly Unrelated Regressions Augmented Dickey-Fuller (SURADF) test.

\section{THE DATA}

The paper uses annual, nominal, end-of-period exchange rates and price indices to construct real US dollarbased exchange rates for twelve Arab countries namely Algeria, Bahrain, Egypt, Jordan, Kuwait, Morocco, Oman, Saudi Arabia, Sudan, Syria, Tunisia and United Arab Emirates (UAE). The choice of countries was determined by data availability. The real exchange rate is calculated as follows:

$\mathrm{q}=\mathrm{e}+\mathrm{p}^{*}-\mathrm{p}$

where $\mathrm{q}$ is the logarithm of the real exchange rate, e is the logarithm of the nominal dollar exchange rate of the domestic country (defined as the domestic price of one unit of foreign exchange), $\mathrm{p}^{*}$ is the logarithm of the US price index, and $\mathrm{p}$ is the logarithm of the domestic country's price index. The price index used is the Consumer Price Index (CPI) except for Oman, Tunisia and UAE for which the CPI was not available. For these three countries the price index used is the GDP deflator and is related to the GDP deflator of the United States. The data covers the period 1969 to 2002 (the longest span of data available for the twelve countries) and was obtained from the International Monetary Fund's International Financial Statistics CD-ROM for June 2004.

\section{UNIT ROOT TESTS}

\section{The Univariate ADF Test for Unit Roots}

The first step taken is to test for unit roots in the real exchange rates of the twelve countries using the univarite ADF test. In this test, the first difference of the logarithm of the real exchange rate is regressed on a constant, the lagged level of the real exchange rate and $\mathrm{k}$ lagged first differences as follows:

$$
\Delta q_{t}=\mu+\alpha q_{t-1}+\sum_{i=1}^{k} c_{i} \Delta q_{t-i}+\varepsilon_{t} .
$$


The number of lags is chosen using the recursive general-to-specific t-test procedure shown by Campbell and Perron (1991) and $\mathrm{Ng}$ and Perron (1995) to have better size and power properties than methods based on information criteria. Maximum $\mathrm{k}$ is set at 4 (a reasonable number with 34 observations) and significance is determined at the $10 \%$ level of the asymptotic normal distribution. The null hypothesis of a unit root is rejected in favor of the alternative of level stationarity if $\alpha$ is significantly different from zero.

The results of the ADF test are reported in Table (1).The univariate ADF test finds evidence of PPP by rejecting the unit root null for only two out of the twelve countries: Egypt at the 10\% level and UAE at the 5\% level. The support for the PPP theory obtained by conducting the ADF unit root test on the real exchange rates of the twelve countries can be described as weak at best.

One possible explanation for the results of the ADF test is the low power of these tests with short time spans of data. This makes it difficult to reject the null hypothesis of a unit root in real exchange rates using these univariate tests. To overcome this problem, researchers have recently turned to the use of panel unit root tests to benefit from the extra information obtained from combining time series and cross-sectional data. The paper now turns to using panel methods to investigate whether they will render more support to the PPP hypothesis in this group of countries.

\section{Panel Unit Root Tests}

\section{Im, Pesaran and Shin (IPS) test}

In a recent study, Hassanain (2004) applies the IPS (2003) test and finds evidence of the mean reversion property of the real exchange rate in a panel of 10 Arab countries between 1980 and 1999.The next step therefore is to conduct the IPS test on the panel used in this paper to find out if similar results can be obtained. In addition to the full panel, we also apply the IPS test to two sub-panels. The first is the sub-panel of Non-OPEC countries which includes the 8 countries in the original panel that are not members of the Organization of the Petroleum Exporting Countries (OPEC) namely Bahrain, Egypt, Jordan, Morocco, Oman, Sudan, Syria and Tunisia. The second is the sub-panel of OPEC countries that includes the remaining 4 countries in the full panel and that are members of this organization namely Algeria, Kuwait, Saudi Arabia and UAE. The latter countries are big exporters of oil the price of which is denominated in dollars. It is therefore interesting to see if this fact can help reduce the volatility of their currencies in relation to the dollar and so cause PPP to hold when the dollar is used as the base currency.

The IPS procedure tests the null of the existence of a unit root in every series in the panel against the alternative that at least one series does not have a unit root. The test is based on averaging the t-statistics on the $\alpha$ 's obtained from univariate ADF tests conducted on the different countries in the panel. Using independent tests for the different countries allows for heterogeneity in the lag-structures of the different series to account for serial correlation. It also allows for the autoregressive coefficient to vary across panel members and thus attribute to the good power and size properties of the test. Moreover, by using cross-sectionally de-meaned regressions, the test also accounts for contemporaneous cross-correlations among the countries in the panel. For $\mathrm{i}=1, \ldots \ldots, \mathrm{N}$ countries and $\mathrm{t}=1, \ldots \ldots, \mathrm{T}$ time periods, the $\mathrm{t}$-bar statistic is defined as

$$
\psi_{t}=\frac{\sqrt{N}\left\{\bar{t}_{N T}-\frac{1}{N} \sum_{i=1}^{N} E\left[t_{i T} \mid \alpha_{i}=0\right]\right\}}{\sqrt{\frac{1}{N} \sum_{i=1}^{N} \operatorname{Var}\left[t_{i T} \mid \alpha_{i}=0\right]}}
$$


Where $\quad \bar{t}_{N T}=\frac{1}{N} \sum_{i=1}^{N} t_{i T}$ and $t_{i T}$ is the individual ADF t-statistic for testing $\square_{\mathrm{i}}=0$. The values of $E\left[t_{i T} \mid \alpha_{i}=0\right]$ and $\operatorname{Var}\left[t_{i T} \mid \alpha_{i}=0\right]$ evaluated via stochastic simulations are reported in Table (2) of Im et al. (2003). The critical values for $\bar{t}_{N T}$ statistic have also been computed by stochastic simulations and are reported in Table (4) of Im et al. (2003).

The results of applying the IPS test to the real exchange rates of the panel of the twelve countries as well as to the Non-OPEC and OPEC sub-panels are reported in Table (2). In the case of the full panel and the Non-OPEC sub-panel, the null hypothesis of a unit root is rejected at the $1 \%$ level. On the other hand, the IPS test fails to reject the null in case of the OPEC sub-panel. The IPS test does not seem to give evidence that the fact that a big part of these countries exports namely their oil exports is denominated in dollars particularly helps PPP to hold for these countries with the dollar as the numeraire currency. The rejection of the unit root null for the full panel is in agreement with the result previously obtained by Hassanain (2004). However, it is important not to overstate the implication of this result with regards to the validity of PPP for these countries. The test simply concludes that at least one series (but not necessarily all the series) does not have a unit root- a result that does not seem to give more support to the PPP theory than that given by the univariate ADF test. The rejection of the null can be viewed as strongly supportive of PPP if it meant that all the real exchange rate series are stationary. This requires running a test with a different alternative hypothesis such as that of Levin, Lin and Chu (2002).

Levin and Lin $(L L)$ test

The Panel unit root test used here is a version of the LL (2002) procedure that involves estimating the following equation by feasible GLS using Seemingly Unrelated Regressions GLS(SUR):

$$
\Delta q_{j t}=\mu_{j}+\alpha q_{j t-1}+\sum_{i=1}^{k} c_{i j} \Delta q_{j t-i}+\varepsilon_{j t}
$$

Where $\mathrm{j}=1, ., 12$ denotes the countries. This test accounts both for serial and contemporaneous correlation ${ }^{3}$. The model used does not include a trend but includes heterogeneous intercepts which is equivalent to including countryspecific fixed effects. Levin et al. (2002) show that using heterogeneous intercepts considerably reduces the gain in power compared to using homogeneous intercepts, because in this case each additional country in the sample adds an extra parameter to be estimated. However, the variation in the value of the coefficient $\mu$ reported in Table (1) does not justify using homogeneous intercepts. The autoregressive coefficient $\alpha$ is restricted to be the same for all countries under both the null and alternative hypotheses because of the definition of the LL panel test. The values of $\mathrm{k}$ are taken from the results of the univariate ADF tests reported in Table (1) and the null hypothesis of a unit root panel is rejected in favor of level stationarity of all the series in the panel if $\alpha$ is significantly different from zero. Again, the LL test is conducted for the full panel as well as for the Non-OPEC and OPEC sub-panels.

Exact finite sample critical values for the test statistic that account for both serial and contemporaneous correlation in the disturbances are computed using Monte Carlo methods for the full panel and the two sub-panels. This is done by fitting autoregressive (AR) models to the first differences of each of the real exchange rate series and using the Bayesian information criterion to choose the optimal AR models which are then treated as the true datagenerating processes for the errors of each of the series. From the generated residuals, the covariance matrix $\sum$ is calculated which preserves the cross-sectional dependence in the data. For each of the panels, the optimal AR model with iid $\mathrm{N}\left(0, \sum\right)$ innovations is used to construct pseudo samples of size equal to the actual size of the series. Partial sums are then taken so the generated series have a unit root by construction. The estimation procedure of the test is conducted on the generated data and the process is repeated 5000 times to obtain the critical values for the finite sample distributions from the sorted vector of the replicated statistics. 
The results of the LL-type panel unit root test as well as the critical values for each panel are reported in Table (3). For the full panel, the null can only be weakly rejected at the $10 \%$ level. For the Non-OPEC sub-panel the rejection occurs at the 5\% level. The LL-type test, however, fails to reject the unit root null for the sub-panel of OPEC countries. Again, the issue of the dollar-denominated oil exports does not seem to be an important factor here.

To check the robustness of the results, the test is performed on panels that exclude the countries for which the ADF test showed evidence against the unit root null. The results are again given in Table (3). The robustness test shows the weakness of the results. For the full panel, we are unable to reject the null once we remove either UAE or Egypt from the panel. Similarly, once Egypt is excluded from the non-OPEC sub-panel, the unit root rejection disappears. This gives evidence that the unit root rejections that were obtained are in fact driven by the stationary exchange rates in the panel and that once those are removed the evidence for PPP can no longer be found.

This seems to imply that the panel of the 12 countries is probably a mix of stationary and unit root series. In spite of the welcome gain in power that is obtained with LL-type tests, their all-or-nothing nature does not provide much information about the individual series is cases of mixed panels. In an attempt to gain such insight, the task of the next section is to conduct a newly-developed panel unit root test that allows investigating the unit root behavior of each individual panel member.

\section{The Seemingly Unrelated Regressions Augmented Dickey-Fuller (SURADF) Test}

The LL test has been criticized $^{4}$ for imposing a common value of the autoregressive parameter across all the panel members under both the null and alternative hypotheses. Referring to Equation (2), the null and the alternative hypotheses would be specified as follows:

$\mathrm{H}_{0}: \alpha_{1}=\alpha_{2}=\ldots=\alpha_{\mathrm{N}}=0$

$\mathrm{H}_{1}: \alpha_{1}=\alpha_{2}=\ldots=\alpha_{\mathrm{N}}<0$

This meant that ALL series could be unit root or ALL could be stationary with identical autoregressive coefficients; a restrictive assumption. This triggered a number of alternative panel unit root tests that released this restriction under the alternative hypothesis such as those developed in Im et al. (2003), Maddala and Wu (1999), Sarno and Taylor (1998) and Taylor and Sarno (1998). These tests, however, maintain the not-very-informative alternative hypothesis of "at least one of the series" is stationary but do not distinguish the unit root from the stationary series. To address this problem, a new test was developed by Breuer, McNown and Wallace (2002) namely the SURADF test. The SURADF procedure tests separate null and alternative hypotheses for each member of the panel within a SUR framework. Referring again to Equation (2), the SURADF test specifies the null and alternative hypotheses as follows:

$\begin{array}{cc}\mathrm{H}_{0}{ }^{1}: \alpha_{1}=0 & \mathrm{H}_{\mathrm{A}}{ }^{1}: \alpha_{1}<0 \\ \mathrm{H}_{0}{ }^{2}: \alpha_{2}=0 & \mathrm{H}_{\mathrm{A}}{ }^{2}: \alpha_{2}<0 \\ \cdot & \cdot \\ \cdot & \mathrm{H}_{\mathrm{A}}{ }^{\mathrm{N}}: \alpha_{\mathrm{N}}<0\end{array}$

The test-statistic for each of the twelve series is calculated as the t-statistic for the coefficient on the lagged level in the equation for this series. The test-statistics are obtained from SUR estimates of Equation (2) over all the panel members. This structure of the hypotheses differs from that of the univariate ADF test in that the SUR model, which accounts for the contemporaneous cross-correlation of the error terms, is used to produce efficient and potentially more powerful estimators and test statistics. Moreover, the test does not impose any restrictions across the members of the panel under the null or the alternative hypotheses. Thus, the test does not only give conclusions about the whole panel but it also identifies the panel members that reject or do not reject the unit root null. The SURADF test also accounts for heterogeneous serial correlation across panel members. To get more intuition into the support for PPP in this panel of twelve countries, the SURADF test is conducted on the full panel. 
The test statistics obtained from the SURADF procedure have a non-standard distribution and thus bootstrap critical values for this one-tailed test are calculated through simulations. These simulations use the individual lag structures and the variance-covariance matrix obtained from the SUR estimation. The resulting critical values are specific to the number of countries in the panel, the number of observations and the estimated covariance matrix for the series. A separate distribution will be produced for each panel member's test statistic. Breuer et al. (2002) conduct simulations and prove that the SURADF test provides a substantial gain in power when compared with the univariate ADF test. ${ }^{5}$

The test statistics of the SURADF test as well as the simulated critical values are given in Table (4). The SURADF test can reject the unit root null for only two out of the twelve countries: UAE at the $1 \%$ level and Oman at the 5\% level. It is impossible not to notice that the results of the SURADF procedure are different from those of the univariate ADF tests. The countries for which the unit root null is rejected by the ADF test are not exactly the same as those for which it is rejected by the SURADF test; The ADF test rejects the null for UAE and Egypt while the SURADF rejects it for UAE and Oman. Thus a power analysis is conducted for the two tests by means of simulations following the procedure used in Breuer et al. $(2001,2002)$. Power is determined by the percent of rejections of the null using the SURADF 5\% critical values found in Table (4) and the ADF 5\% critical value of $-2.95 .^{6}$ The results of the power analysis are given in Table (5).

The results indicate that, in all cases, the power of the SURADF exceeds that of the ADF test. Comparing the figures shows that in some cases the power more than doubled. This gain in power can explain why the unit root null could be rejected with the SURADF test although that rejection could not be achieved with the ADF test i.e. in the case of Oman. As for the opposite scenario, the explanation is a little less obvious. Breuer et al. (2001) give a number of reasons why such cases can occur. One reason could be the extra information introduced into the estimation by a nonzero covariance matrix which implies the existence of contemporaneous correlation in the panel that needs to be accounted for to get correct results. Another reason, is that with the SURADF test the $\alpha$ 's may move closer or further away from zero causing a change in inference. A third reason is that the critical values for SURADF are higher in absolute value than those of the ADF test making it more difficult to reject the null even if the standard errors are reduced ( due to the information from the covariance matrix) and the implied autoregressive coefficient moves away from 1.

Going back to the results of the SURADF test, we find that even with the increase in power achieved with this test over the ADF test, the support for PPP remains fragile. This confirms the conclusion that was drawn from the previous tests: the support for PPP in the real exchange data of these twelve Arab countries seems to be weak.

\section{DISCUSSION OF THE RESULTS}

The results indicate that evidence for mean reversion in this panel of twelve Arab countries remains in general weak. Researchers ${ }^{7}$ give many reasons for deviations from the Law of One Price and PPP. Among those reasons is stickiness in nominal prices in the short run so that financial and monetary shocks that affect nominal exchange rates translate into short run changes in the real exchange rate (Dornbusch's (1976) overshooting model). Another explanation for the failure of goods market arbitrage to equalize international prices is the presence of transaction costs like transportation costs, tariffs, non-tariff barriers etc. all of which create a wedge between domestic and foreign prices. Yet another factor is the presence of many non-traded goods in countries' price indices and the fact that even highly traded goods contain many non-traded components such as service and property rental components. The list also includes pricing to market, Krugman's idea of price discrimination across international markets, whereby prices in export markets are set in the consumers' currency rather than that of the producer and thus changes in nominal exchange rates do not affect goods prices in these markets; this zero pass-through of exchange rate changes to local prices results in deviations from PPP. Moreover deviations from PPP can arise from the fact that the baskets of goods used to build price indices in different countries are not standardized but differ across countries.

Which of those reasons explain the weak evidence for PPP in the panel of Arab countries? It could be a little bit of everything. Many of the countries in the panel (over most of the period of the data) adopt exchange rate systems in which they peg their currencies to that of a developed country mainly the U.S. dollar as in Saudi Arabia, Oman, 
Bahrain, and UAE or to a composite dominated by the dollar like Kuwait. When the real exchange rate deviates from PPP, adjustment can come either from changes in the nominal exchange rate or prices. With the nominal rate being pegged, price adjustment becomes the leeway for the real exchange rate to re-adjust. The fact that in Arab countries price controls are very widespread and that price indices reflect those controlled prices, makes adjustment of the real exchange rate even harder. As a matter of fact if the price levels in these countries (as measured by their CPI's) are controlled, then any fluctuations in the nominal exchange rate will lead to deviations from PPP. Also being developing countries, members of this panel often resort to imposing tariffs to protect their infant industries which add to the wedge between domestic and international prices created by other transaction costs like transport costs, insurance etc. Moreover, the baskets used to build price indices in these developing countries are likely to differ from those of developed economies both in the types of goods included in the baskets and in the weights assigned to them. Probably many of those are features that these countries share to one degree or the other with most of the countries of the world or at least the developing world but they make the violation of PPP a possibility, nevertheless.

A second look at the results shows that UAE seems to be the country for which the unit root null can be consistently rejected and thus gives the most support to PPP. If we take into consideration that the SURADF proved to have more power than the ADF test, then we can also consider Oman to show evidence for PPP, though the unit root rejection is weaker for Oman than UAE. Papell and Theodoridis (2001) find that the ability to find evidence for PPP is inversely related to distance and nominal exchange rate volatility between the base currency and other currencies. It is unlikely that distance could give the explanation as to why the result was different for these two countries since UAE and Oman are not any closer to the United States than any of the other countries in the panel. As for volatility, these are two countries that peg their exchange rates to the dollar and therefore volatility (i.e. lack of) in the nominal exchange rates could give part of the answer for the stability in the real rates. However, other countries in the panel also peg their currencies to the dollar but no evidence for PPP could be found for them as a result of the lack of volatility in the nominal exchange rate. As a matter of fact as mentioned above pegging a country's currency to a major currency like the dollar can act as a source of deviation from PPP when the nominal exchange rate fluctuates unless these fluctuations are accompanied by price adjustments through goods market arbitrage. The distinguishing feature of UAE and Oman seems to be that they are both free market economies with very little price controls and in which market forces largely determine prices. Moreover, these two countries impose the lowest tariffs of all the countries in the panel ${ }^{8}$; Oman's import custom duties are about $5 \%$ while the highest customs duty for the UAE is $4 \%$ with more than $75 \%$ of imports entering the country duty free. These duties are much lower than those collected by other countries in the panel like 12\% (recently reduced to 5\%) by Saudi Arabia, 10\% (recently reduced to 7.5\% on consumer goods) by Bahrain and definitely lower than the Average Most Favored Nation duties of 27\% collected by Egypt (reduced in the beginning of 2000 from a high of $42 \%$ in 1991). It seems that the removal of some of the sources of wedges between domestic and foreign prices helped maintain PPP for these two particular countries. In other words, simply allowing for the goods market arbitrage to occur was the magical ingredient in this case.

As a result of the rules of the WTO, trade agreements signed between Arab and non-Arab countries like those signed with the European Union by Morocco and Tunisia, and agreements within Arab countries like the Gulf Cooperation Council (GCC) agreement to form a Customs Union; tariffs have been quickly reduced in Arab countries over the past few years with more cuts planned in the near future. Also with the move by more and more Arab countries towards becoming free market economies (in many cases due to IMF programs), price controls are being gradually eliminated allowing for prices to be increasingly determined by market forces. This should give the other Arab countries more of the price flexibility that helped support PPP in the case of UAE and Oman.

\section{CONCLUSIONS}

The paper tests the validity of the theory of purchasing power parity (PPP) using a panel of twelve Middle Eastern Arab countries. For this purpose, four different unit root procedures are applied to test for the mean reversion property in the real exchange rates of these twelve countries. The evidence supporting PPP in this panel is generally found to be weak. The paper concludes that in the case of the countries for which support for PPP is found, the explanation lies in these countries' pricing and foreign trade policies. 


\section{ENDNOTES}

${ }^{1}$ A survey of this literature is found in Taylor and Taylor (2004).

${ }^{2}$ Hassanain (2004) uses a panel of 10 countries that includes the same countries in the panel used in this paper except Algeria, Oman and UAE. His panel also includes Qatar.

${ }^{3}$ Papell (1997) modifies the LL test to account for heterogeneous serial correlation. He shows that serial correlation has an impact on the size of panel unit root tests.

${ }^{4}$ A detailed discussion can be found in Breuer et al.(2001).

${ }^{5}$ A detailed description of the SURADF test, the power analysis, and the procedure for simulating the bootstrap critical values can be found in Bruer et al. (2002).

${ }^{6}$ In constructing the stationary series used in the power test, the value of the coefficient on the lagged level was set once to be equal to -0.10 and once to be equal to -0.20 (which is a good approximation given the range of values for $\alpha$ in Table 4).

${ }^{7}$ Studies that dealt with such violations include Dornbusch (1976), Krugman (1987), Knetter (1993), Rogers and Jenkins (1995), Engel and Rogers (2001) and Rogoff (1996).

${ }^{8}$ The information on import custom duties was obtained from the U.S. Department of State Website: Bureau of Economic and Business Affairs: Reports on Economic Policy and Trade Practices.

\section{REFERENCES}

1. Bahmani-Oskooee, M. (1998), Do Exchange Rates Follow a Random Walk Process in Middle Eastern Countries? Economics Letters, Vol. 58, No.3, pp. 339-44.

2. Breuer, J., McNown, R., and M. Wallace (2001), Misleading Inferences from Panel Unit-Root Tests with an Illustration from Purchasing Power Parity, Review of International Economics, Vol. 9, No.3, pp. 482-93.

3. Breuer, J., McNown, R., and M. Wallace (2002), Series-Specific Unit Root Tests with Panel Data, Oxford Bulletin of Economics and Statistics, Vol. 64, No.5, pp. 527-46.

4. Campbell, J. and P. Perron (1991), Pitfalls and Opportunities: What Macroeconomists Should Know About Unit Roots, NBER Macroeconomics Annual, pp. 141-201.

5. Dornbusch, R. (1976) Expectations and Exchange Rate Dynamics, Journal of Political Economy, Vol. 84, No.6, pp. 1161-76.

6. Edwards, S. (1989), Real Exchange Rate Devaluation and Adjustment, The MIT Press, Cambridge.

7. Engel, C. and J. Rogers (2001), Deviations from Purchasing Power Parity: Causes and Welfare Costs, Journal of International Economics, Vol. 55, No.1, pp. 29-57.

8. Hassanain, K. (2004), Purchasing Power Parity: Further Evidence and Implications, Review of Middle East Economics and Finance, Vol. 2, No.1, pp. 63-77.

9. Im, K., Pesaran, M., and Y. Shin (2003), Testing for Unit Roots in Heterogeneous Panels, Journal of Econometrics, Vol. 115, No.1, pp. 53-74.

10. Knetter, M. (1993), International Comparisons of Price-to-Market Behavior, American Economic Review, Vol. 83, No.3, pp. 473-86.

11. Krugman, P. (1987), Pricing to Market When the Exchange Rate Changes, in S. Arndt and J. Richardson (eds.), Real-Financial Linkages among Open Economies. The MIT Press, Cambridge, pp. 49-70.

12. Kwiatkowski, D., Phillips, P., Schmidt, P., and Y. Shin (1992), Testing the Null Hypothesis of Stationarity against the Alternative of a Unit Root: How Sure Are We that Economic Time Series Have a Unit Root? Journal of Econometrics, Vol. 54, No.1/2/3, pp.159-78.

13. Levin, A., Lin, C., and C. Chu (2002), Unit Root Tests in Panel Data: Asymptotic and Finite Sample Properties, Journal of Econometrics, Vol. 108, No.1, pp.1-24.

14. Mackinnon, J. G. (1991), Critical Values for Cointegration Tests, in R. F. Engle and C. W. J. Granger (eds.), Long Run Economic Relationships: Readings in Cointegration. Oxford University Press, Oxford, pp. 267-76.

15. Maddala, G. and S. Wu (1999), A Comparative Study of Unit Root Tests with Panel Data and a New Simple Test, Oxford Bulletin of Economics and Statistics, Vol. 61, No.4, pp. 631-52.

16. Ng, S. and P. Perron (1995), Unit Root Tests in ARMA Models with Data-Dependent Methods for the Selection of the Truncation Lag, Journal of the American Statistical Association, Vol. 90, No.429, pp. 26881. 
17. Papell, D. (1997), Searching for Stationarity: Purchasing Power Parity Under the Current Float, Journal of International Economics, Vol. 43, No.3-4, pp. 313-32.

18. Papell, D. and H. Theodoridis (2001), The Choice of Numeraire Currency in Panel Tests of Purchasing Power Parity, Journal of Money, Credit, and Banking, Vol. 33, No.3, pp. 790-803.

19. Rogers, J. and M. Jenkins (1995), Haircuts or Hysteresis? Sources of Movements in Real Exchange Rates, Journal of International Economics, Vol. 38, No. 3/4, pp. 339-60.

20. Rogoff, K. (1996), The Purchasing Power Parity Puzzle, Journal of Economic Literature, Vol. 34, No.2, pp. 647-68.

21. Salehizadeh, M. and R. Taylor (1999), A Test of Purchasing Power Parity for Emerging Economies, Journal of International Financial Markets, Institutions and Money, Vol. 9, No.2, pp.183-93.

22. Sarno, L. (2000), Real Exchange Rate Behavior in the Middle East: A Re-examination, Economics Letters, Vol. 66, No.2, pp.127-36.

23. Sarno, L. and M. Taylor (1998), Real Exchange Rates Under the Recent Float: Unequivocal Evidence of Mean Reversion, Economics Letters, Vol. 60, No.2, pp. 131-37.

24. Soofi, A. (1998), A Fractional Cointegration Test of Purchasing Power Parity, the Case of Selected Members of OPEC, Applied Financial Economics, Vol. 8, No.6, pp. 559-66.

25. Taylor, A. and M. Taylor (2004), The Purchasing Power Parity Debate, Journal of Economic Perspectives, Vol. 18, No. 4, pp. 135-58.

26. Taylor, M. and L. Sarno (1998), The Behavior of Real Exchange Rates during the Post Bretton Woods Period, Journal of International Economics, Vol. 46, No.2, pp. 281-312.

Table (1) ADF Unit Root Test

\begin{tabular}{|c|c|c|c|}
\hline Country & $\mathbf{m}$ & $\mathbf{a}$ & $\mathbf{K}$ \\
\hline Algeria & $\begin{array}{l}0.006 \\
(0.07)\end{array}$ & $\begin{array}{l}0.004 \\
(0.08) \\
\end{array}$ & 0 \\
\hline Bahrain & $\begin{array}{l}-0.051 \\
(-2.19)\end{array}$ & $\begin{array}{l}-0.093 \\
(-2.18)\end{array}$ & 1 \\
\hline Egypt & $\begin{array}{l}0.146 \\
(2.74)\end{array}$ & $\begin{array}{c}-0.294 \\
(-2.73)^{*}\end{array}$ & 1 \\
\hline Jordan & $\begin{array}{l}-0.027 \\
(-1.48)\end{array}$ & $\begin{array}{l}-0.118 \\
(-1.61)\end{array}$ & 1 \\
\hline Kuwait & $\begin{array}{l}-0.028 \\
(-0.69)\end{array}$ & $\begin{array}{l}-0.051 \\
(-0.78)\end{array}$ & 0 \\
\hline Morocco & $\begin{array}{l}0.138 \\
(2.05)\end{array}$ & $\begin{array}{l}-0.150 \\
(-2.04)\end{array}$ & 1 \\
\hline Oman & $\begin{array}{l}-0.084 \\
(-2.42)\end{array}$ & $\begin{array}{l}-0.182 \\
(-2.33)\end{array}$ & 0 \\
\hline Saudi Arabia & $\begin{array}{l}0.038 \\
(2.30)\end{array}$ & $\begin{array}{l}-0.088 \\
(-2.29)\end{array}$ & 2 \\
\hline Sudan & $\begin{array}{l}0.788 \\
(2.53)\end{array}$ & $\begin{array}{c}-0.35 \\
(-2.52)\end{array}$ & 0 \\
\hline Syria & $\begin{array}{l}0.129 \\
(1.35)\end{array}$ & $\begin{array}{l}-0.115 \\
(-1.50)\end{array}$ & 0 \\
\hline Tunisia & $\begin{array}{l}0.003 \\
(0.49)\end{array}$ & $\begin{array}{l}-0.103 \\
(-1.15)\end{array}$ & 0 \\
\hline UAE & $\begin{array}{l}0.115 \\
(2.89)\end{array}$ & $\begin{array}{c}-0.203 \\
(-3.39)^{* *}\end{array}$ & 0 \\
\hline
\end{tabular}

Critical Values for ADF tests

\begin{tabular}{|c|c|c|}
\hline $\mathbf{1 \%}$ & $\mathbf{5 \%}$ & $\mathbf{1 0 \%}$ \\
\hline-3.64 & -2.95 & -2.61 \\
\hline
\end{tabular}

Note: t-statistics are in parentheses. $* *$ and $*$ denote statistical significance at $5 \%$ and $10 \%$ levels respectively. The critical values are obtained from MacKinnon (1991) adjusted for 34 observations. 
Table (2) IPS Test Results

\begin{tabular}{|l|c|}
\hline Countries & Standard t-bar statistic \\
\hline Full Panel & $-2.84^{* * * *}$ \\
\hline Non-OPEC Countries & $-3.22^{* * * *}$ \\
\hline OPEC Countries & -0.37 \\
\hline
\end{tabular}

\section{Critical Values for IPS Test}

\begin{tabular}{|ll|l|l|l|}
\hline & & $\mathbf{1 \%}$ & $\mathbf{5 \%}$ & $\mathbf{1 0 \%}$ \\
\hline $\mathrm{N}=10$ & $\mathrm{~T}=30$ & -2.18 & -1.99 & -1.88 \\
\hline $\mathrm{N}=5$ & $\mathrm{~T}=30$ & -2.44 & -2.16 & -2.02 \\
\hline
\end{tabular}

Note: $* * *$ denotes statistical significance at the $1 \%$ level. The critical values with $\mathrm{N}=10$ are used for the full sample while those with $\mathrm{N}=5$ are used for the two sub-samples.

Table (3) LL Test Results

\begin{tabular}{|l|c|c|c|c|c|}
\hline \multirow{2}{*}{ Countries } & \multirow{2}{*}{$\mathbf{T}_{\boldsymbol{\alpha}}$} & \multicolumn{3}{|c|}{ Critical Values } \\
\cline { 3 - 6 } & & $-7.83^{*}$ & $\mathbf{1 \%}$ & $\mathbf{5 \%}$ & $\mathbf{1 0 \%}$ \\
\hline Full Panel & -0.155 & -6.62 & -8.93 & -7.86 & -7.39 \\
\hline Exclude UAE & -0.137 & -7.28 & -8.53 & -7.45 & -6.91 \\
\hline Exclude Egypt & -0.146 & $-6.15^{* *}$ & -7.11 & -7.51 & -6.99 \\
\hline Non-OPEC & -0.162 & -5.37 & -6.64 & -6.14 & -5.69 \\
\hline Exclude Egypt & -0.149 & -3.27 & -5.46 & -5.80 & -5.38 \\
\hline OPEC & -0.081 & & & -4.57 & -4.10 \\
\hline
\end{tabular}

\section{Table (4) SURADF Test Results}

\begin{tabular}{|l|c|c|c|c|c|}
\hline \multirow{2}{*}{ Country } & \multirow{2}{*}{} & \multirow{2}{*}{$\mathbf{t}_{\boldsymbol{\alpha}}$} & \multicolumn{3}{|c|}{ Critical Values } \\
\cline { 3 - 6 } & -0.009 & -0.19 & $\mathbf{1 \%}$ & $\mathbf{5 \%}$ & $\mathbf{1 0 \%}$ \\
\hline Algeria & -0.098 & -2.81 & -5.38 & -4.39 & -3.89 \\
\hline Bahrain & -0.297 & -3.49 & -5.56 & -4.53 & -4.03 \\
\hline Egypt & -0.145 & -2.99 & -5.35 & -4.44 & -3.91 \\
\hline Jordan & -0.144 & -2.61 & -5.01 & -4.97 & -4.48 \\
\hline Kuwait & -0.196 & -3.39 & -5.76 & -4.55 & -4.04 \\
\hline Morocco & -0.378 & $-5.64^{* *}$ & -6.06 & -4.66 & -4.19 \\
\hline Oman & -0.103 & -3.29 & -5.80 & -4.69 & -4.51 \\
\hline Saudi Arabia & -0.351 & -2.07 & -5.21 & -4.28 & -4.17 \\
\hline Sudan & -0.121 & -1.84 & -5.52 & -4.53 & -3.78 \\
\hline Syria & -0.217 & -2.94 & -6.03 & -5.07 & -4.05 \\
\hline Tunisia & -0.408 & $-6.41^{* * * * *}$ & -5.82 & -4.85 & -4.58 \\
\hline UAE & & & & -4.33 \\
\hline
\end{tabular}


Table (5) Power function Analysis

\begin{tabular}{|c|c|c|c|c|}
\hline & \multicolumn{4}{|c|}{ Rejection Rates (Power) } \\
\hline & \multicolumn{4}{|c|}{ Coefficient on lagged level } \\
\hline & \multicolumn{2}{|c|}{-0.1} & \multicolumn{2}{|c|}{-0.2} \\
\hline Country & ADF & SURADF & ADF & SURADF \\
\hline Algeria & 0.0966 & 0.1324 & 0.2168 & 0.2862 \\
\hline Bahrain & 0.2172 & 0.3290 & 0.5060 & 0.7046 \\
\hline Egypt & 0.1404 & 0.1614 & 0.3398 & 0.3764 \\
\hline Jordan & 0.1252 & 0.2710 & 0.2872 & 0.6196 \\
\hline Kuwait & 0.0954 & 0.1258 & 0.1824 & 0.2892 \\
\hline Morocco & 0.1292 & 0.2440 & 0.3382 & 0.5498 \\
\hline Oman & 0.1090 & 0.1524 & 0.2426 & 0.3760 \\
\hline Saudi Arabia & 0.3146 & 0.5910 & 0.4988 & 0.8186 \\
\hline Sudan & 0.0628 & 0.0946 & 0.1014 & 0.1422 \\
\hline Syria & 0.0882 & 0.1012 & 0.1378 & 0.1856 \\
\hline Tunisia & 0.0958 & 0.1328 & 0.1920 & 0.3132 \\
\hline UAE & 0.1360 & 0.1752 & 0.3146 & 0.4428 \\
\hline
\end{tabular}

\section{NOTES}




\section{NOTES}

